\title{
Towards a Balanced Policy Mix under EMU: Co-ordination of Macroeconomic Policies and 'Economic Government'?
}

\author{
Ansgar Belke \\ University of Hohenheim
}

\begin{abstract}
What kind of additional co-operation (-ordination) is necessary and feasible to cope with the new institutional set-up under EMU? Starting from the episode of the repo rate cut by the ECB in early 1999, it is asked what would have happened under a business as usual scenario. In this case, the pre-Maastricht pattern of fiscal policy would have quickly led to grave problems. A promising alternative monetary-fiscal policy mix in the first half of 1999 consisted of a restrictive fiscal policy and a monetary policy which had - within the bounds of price stability some leeway to act counter-cyclically.
\end{abstract}

- JEL Classifications: E58, E61, E63

- Key Words: EMU, Fiscal and Monetary Policy, Policy Coordination, Policy Mix, Policy Rules

\section{Introduction}

Today, Euroland is characterised by a situation of enhanced interdependence. Its policy mix is determined by a three-level-game between a europeanised monetary policy, eleven respectively twelve nation specific fiscal policies (which are coordinated by the Stability and Growth Pact) and a wage- (and price-) setting whose institutional set-ups are fairly different. The domain of wage bargains will be an increasingly decentralised one. The main difference with the pre-EMU situation is constituted by the fact that macroeconomic policy does not result from

\footnotetext{
*Corresponding address: Ansgar Belke, University of Vienna, Hohenheim, Germany, Tel: +49-7114593247, Fax: +49-7114593815, E-mail: belke@uni-hohenheim.de (C2002-Center for International Economics, Sejong Institution, All Rights Reserved.
} 
players engaged on the same level any more (i.e., triangle of co-operation in Germany). Thus, what concerns strategic net power, monetary policy can be described as the main winner of the new EMU institutional set-up. The latter can best be described as a triangle of co-operation (Gretschmann (1999), Kösters, Kotz (1999)). The question automatically arises what kind of additional cooperation or even co-ordination is necessary and feasible in order to cope with this new EMU institutional set-up, i.e. how to reach an appropriate and balanced policy mix in Euroland which fosters growth and employment (see for example Gretschmann (1999)). This paper focuses on this important question which is increasingly frequently posed in the political sphere.

Chapter II starts with a brief description of the status-quo of the new policy game under EMU (section II.A) and of the quite undisputed microeconomic policy recommendations for Euroland (section II.B). The respective results serve as reference points with respect to the derivation of macroeconomic policy recommendations. Chapter III sets out the position of this paper on details of an appropriate macroeconomic policy in the first year(s) of the adoption of the euro. It starts in section III.A by asking what would happen under a business as usual scenario and concludes that the pre-Maastricht pattern of fiscal policy would quickly lead to problems. The paper then lays out in section III.B the most promising alternative monetary-fiscal policy mix. In section III.C, it is asked whether global considerations as, e.g., an assessment of the importance of the euro as a foreign reserve currency, would call for a different policy mix. Section III.D argues that prices, and hence temporary inflation differentials instead of fiscal policies constitute the appropriate adjustment mechanism for territorial differences within Euroland. In section IV.A, the main conclusions with respect to the policy mix are explained and justified in detail. Special emphasis is given to the role of the Euro-11 in the proposal for the policy mix. In section IV.B., the remaining and important uncertainties connected with the proposed policy mix are disclosed and discussed. This paper finishes with in chapter $\mathrm{V}$ with a short summary.

\section{The Status-quo: Traces of Co-ordination and Microeconomic Policy Recommendations}

\section{A. A Brief History of the New Macroeconomic Policy Game Under EMU}

When the European leaders started the launch of the euro in May 1998 the 
macroeconomic outlook was extraordinarily good. Growth was fostered, inflation was nearly away, public finances recovered and the balance of payments was significantly in surplus. In autumn two important shocks to economic performance occurred. First, the Asian and the Russian crises had an impact on world trade and led to serious losses of Western financial institutions. In addition, the LTCM hedge fund nearly collapsed and financial markets turned away from risky investment. Survey data indicated that business confidence progressively decreased and forecasts for 1999 were at that time decreased downwards. Second, government changes in Germany and Italy following those one year earlier in France and the UK, led to a vast majority for central-left parties in Euroland. The characteristics of the debate on economic and monetary policy significantly changed. Vocal calls for expansionary policies and a more rigorous co-ordination of tax and social policies increased steadily.

In October and November 1998 in the wake of the elections, there was a public debate on how to manage the new EMU rules for monetary and fiscal policy between governments and the ECB. A series of declarations by ministers of finance and central bankers emerged which seemed to be pointing towards a scenario in which governments might override the norms of the Stability and Growth Pact. By the call for a co-ordinated procedure in this respect, the idea of a 'gouvernement économique' was revived - an idea which has already been propagated by the French prime minister Bérégovoy in the run-up to the Maastricht negotiations and by the newly elected French government in the spring of 1997. The latter alluded to 'European responsibilities concerning labour market and employment policy (Hardes (1999), p. 208). ${ }^{1}$ Financial markets would then push up long-term interest rates in anticipation of bigger future public debt burdens. At the same time, the ECB would feel unable or unwilling to offset in an atmosphere of tension between the ECB and Euroland government (Emerson (1999), p. 4, and 43 ff.).

However, by December 1998 the dangers of this policy mix were more widely recognised and the more coherent strategy of monetary ease combined with budgetary rigour (as in the United States) was propagated. At the level of macroeconomic policy strategy, the arguments for budgetary vigour and monetary

\footnotetext{
${ }^{1}$ The proposals of the new leaders differed with respect to a variety of means, e.g., increasing public investment financed by national budgets with a very loose interpretation of the Stability and Growth Pact, or by EU borrowing or by excess reserves of Euroland central banks. See Gretschmann (1999), and Kotz (1998), p. 126.
} 
ease in the first half year of Euroland have been presented with all clarity by the French Finance Minister Strauss-Kahn (see CEPR (1998a)). Following Emerson (1999), the recommended strategy needs to be agreed between Euroland ministers of finance and then the ECB would have to deliver adequate interest rate reductions (Emerson (1999), p. 46). Average inflation in Euroland countries had in the meantime fallen from $1.6 \%$ in 1997 to $1.1 \%$ in 1998 (in France and Germany inflation reached virtually zero at that time) which indicates a case for interest rates to go down to unusually low levels. In the light of the size of the adverse global shock in 1998, the co-ordinated reduction of interest rates on 3 December 1998 was therefore a step in the right direction (for this evaluation see unanimously CEPR (1999a), Emerson (1999), p. 46). ${ }^{2}$ Most important, the change of the German Finance Minister in march 1999 finally facilitated a greater policy coherence in Euroland since the recommended policy strategy must be clearly and credibly confirmed.

On 8 April 1999, the ECB cut the interest rate to 2.5\%. This could be classified as a further step in an already long lasting period of decline and leads to nominal interest rates at the lowest level in this decade. Real interest rates were not high from a historical perspective as well. The April decision was -perhaps because its bad marketing in the public- subject to many controversies and provided an early signal about the ECB preferences. According to the 'Monitoring the European Central Bank (MECB)' group of the CEPR, three lessons can be drawn from this episode:

First, the ECB clearly responded to the risk of a cyclical increase in unemployment in some countries although it had repeatedly stated in the public that it cannot do anything against unemployment. By its pre-emptive interest rate cut the ECB emphasised that it is able to support counter-cyclical policies instead of 'hiding behind its aim of medium-term price stability' if there is no inflation pressure looming at the horizon. CEPR (1999a), p. 5, refers to the example of Japan in order to demonstrate the possible costs of a wait-and-see strategy for Euroland. There is the danger for monetary policy to become ineffective at interest rate levels close to $1 \%$.

Second, the ECB demonstrated by meeting its decision at a time of a declining

\footnotetext{
${ }^{2}$ As the CEPR (1999a) puts it: "It signalled the de facto existence of monetary union ahead of its de jure start. More importantly, it dispelled fears that ther ESCB might be unable to respond to worsening economic conditions". For stylised facts of the monetary policy stance in Euroland see Coppel, Durand, Viscio (2000) as well.
} 
euro against the dollar, that it is prepared to handle the exchange rate with 'benign neglect' (see also Kotz (1998), p. 124 f.). Since Euroland is much less open to external trade than its individual member countries were before, a 'small-openeconomy' perspective becomes irrelevant and the interest rate cut appears to be an appropriate measure vis-à-vis the start of EMU. ${ }^{3}$

Third, the interest rate cut can best be understood by taking the business cycle stance in individual EMU countries (here: Germany and Italy) instead of the aggregate Euroland data into account. By this, the ECB -against its initial vowsimplicitly looked at national situations. This makes sense if one considers that Germany and Italy with deficits near the ceiling of 3\% set by the Stability and Growth Pact cannot rely on expansionary fiscal policy to boost the economy. The 'hotspots' Spain, Portugal Ireland (and more recently also Finland) are not prevented from exercising fiscal restraint. Moreover, one should worry more about the weak economies affecting the strong than the other way round (CEPR (1999a), p. 5).

The MECB group concludes from these lessons that the monetary strategy of the ECB is “ ... evolving, maturing and gradually stepping out of the shadow of the Bundesbank". Their main argument is that the ECB could alternatively have chosen the easy way and have repeated the often used argument that growth and unemployment are solely the concerns of national authorities. By this, it would have interpreted its mandate too narrowly. However, by following the more difficult way, the ECB has demonstrated its intentions to follow a more balanced approach. The approach can be characterised as balanced since, above all, Wim Duisenberg - president of the European Central Bank - has often been interpreted to express verbally that the interest cut only signalled that the ECB 'had done its part, which shifts the responsibility for a (further) improvement of the bad labour market situation in Euroland unambiguously to the wage negotiating parties. From this perspective, a failure to react in time could have resulted in increasing unemployment, rising budget deficits and a diminishing political support for the ECB (CEPR (1999a), p. 5).

Since the economy recovered unexpectedly well in the last months of 1999, the ECB can in principle raise interest rates when such evidence becomes first available - well before inflation actually sets in (CEPR (1999a), p. 5). This is exactly what was anticipated for the 4 November 1999 and actually happened (see also section IV).

\footnotetext{
${ }^{3}$ Moreover, many analysts stressed the fact that the ECB should anyway have no reason to react to the exchange rate development of the euro since the main reason for the devaluation of the euro in the first half of 1999 consisted of the remarkable business cycle stance in the U.S.
} 


\section{B. Microeconomic Policy Recommendations}

However, the changes of government of 1997 and 1998 boosted a debate about a traditional question: what kind of economic union should go with the monetary union? The introduction of the euro provoked reconsideration of a large set of microeconomic policies important for enterprises. Guidelines for an appropriate microeconomic policy mix are conveyed by the study of Emerson (1999). Here the alternatives consist of what to centralise and what to decentralise in several important domains of microeconomic or structural economic policy. Emerson (1999) looks at the complex fields of competition policy, corporate governance, corporation taxation and pay bargaining (labour markets). The preferred strategy is -on the one hand- to take new centralising actions at the EU level to remove inefficient idiosyncrasies in national policies, which represent hindrances for trans-European business development. Emerson identifies some such cases in the fields of taxation, company law and accounting standards. On the other hand, greater flexibility is indicated in areas where policy innovation and experimentation is still required, e.g., to resolve big problems such as social security and pension funding. More decentralisation in negotiating wage levels in very high unemployment regions is indicated as well.

In detail, the following conclusions with respect to reshaping microeconomic policies can be drawn. Competition policy has a strong legal base and the thrust of policy appears to become even tougher. On the whole, this appears to be justifiable and should not be seriously contested.

Company law and corporate governance systems are little harmonised. The Euroland capital market will intensify pressures for convergence and simplification of the operating conditions of companies with complex European structures. This will be a long road, but an overdue start should be made with accounting standards and the European company statute. There is also a widespread preference among member states for self-regulation of rules of corporate governance which points to a task for European business organisations.

Three principles to govern EU tax policy for the enterprise sector stand out. a) Unfair tax competition should be restrained, both discriminatory incentives to attract foreign investment and systems profiteering from tax evasion by nonresident individuals; b) a large space should be left for legitimate tax competition, without attempts to harmonise rates of corporate or personal income tax; c) cost saving efficiency considerations for enterprises suggest harmonisation of the 
corporation tax base (rather than the rates, towards the US corporate tax practice).

With respect to labour markets one crucial aspect should be stressed. The paradigm for the working of the Euroland labour market should comprise a greater regional differentiation of wages (see Belke, Gros (1998)). With respect to the question of co-ordination of macroeconomic policies the political background and thus the starting point of this paper is the following. The so-called macroeconomic dialogue/discourse respectively cooperation agreed upon in Cologne (June 1999) is generally interpreted as to complete the Luxembourg process (concept of 'employability' instead of focus on 'unemployment', co-ordinated employment strategy, benchmarking techniques, November 1997) and the Cardiff process (June 1998, reforms to improve the capability to innovate and market efficiency). However, even representatives of the German SPD government concede that it is -in spite of the Cologne agreement- not adequate to prescribe the policy mix for Euroland from above - as tried only recently by the former German finance minister Oskar Lafontaine.

Co-ordination (in a narrow sense) of employment policies on a European level has to be rejected since i) the problem of unemployment has to be solved in a decentralised way on regional markets in the first instance by the wage negotiating parties, ii) a transfer of responsibilities for employment to the European level is imminent, iii) the efficiency of active labour market policies is often overestimated in view of targeting problems and displacement effects (i.e. subsidised work places tend to substitute healthy unsubsidised ones), and iv) purely mechanical targets are unsuited as they rouse not well-founded expectations on problem solutions and give way to activism and interventionism (Bogai (1999), Deutsche Bundesbank (1999), Lesch (2000), Sachverständigenrat (1998), pp. 200 f.). ${ }^{4}$ In the light of the mainly structural character of European unemployment, coordination is counter-productive if it prevents necessary adjustments or neglects local informational advantages. The heterogeneity of the EMU labour markets (and labour market problems) and of the country-specific labour market institutions (degree of centralisation et al.) is a further argument to be sceptical with respect to a successful co-ordination of labour market policies (Deutsche Bundesbank (1999), Institut für Arbeitsmarkt- und Berufsforschung (1999)). Similar arguments should let one to argue against co-ordination of tax and social policies. Instead, knowledge-based growth, microeconomically focused labour

${ }^{4}$ However, for an opposing view, see, e.g., Hardes (1999) 
market policies and an activating state of the UK style should be the recommended measures. That is, 'co-opetition' instead of co-ordination should be emphasised.

At the beginning of EMU, policy-makers in Euroland had to decide on the strategic mix of monetary and budgetary policies. In view of the world economic situation at that time a 'wait-and-see' strategy would probably not have done (CEPR (1999), Emerson (1999), p. 43).

\section{Macroeconomic Policy Recommendations: What Has to Be Done? Reshaping Macroeconomic Policy?}

This chapter sets out the position of this paper on macroeconomic policy. It starts in section III.A by asking what would happen under a "business as usual" scenario and concludes that the pre-Maastricht pattern of fiscal policy would quickly lead to problems. It then lays out in section III.B the alternative. In Section III.C it asks whether global considerations would call for a different policy mix. Section III.D argues that prices, and hence temporary inflation differentials constitute the appropriate adjustment mechanism for territorial differences within Euroland.

\section{A. Do Irresistible Forces Pushing for More Public Spending Meet the ECB as an Immovable Object?}

Gros et al. (1999) show in the necessary detail that deficits have improved considerably over the last five years, but that a large part of this improvement might be due to the business cycle and that the quality of the composition of expenditure has deteriorated. The challenge for policy-makers thus remains to avoid a repeat of the experience of the late 1980s, when expenditure was allowed to grow and deficits were not reduced while the upswing was still going on. One reason for this pattern in the past might have been, as shown by Mélitz (1997), that expenditure tends in general to increase during good times. The challenge will be to break this habit because Euroland's economy would seriously suffer from a clash between the seemingly irresistible forces pushing for more public spending and an immovable object, the ECB. It is therefore interesting to briefly analyse what would happen with Euroland if fiscal policy followed simply its old pattern.

The aggregate fiscal policy pattern of the 11 Euroland countries (up to 1995) can be surprisingly well described by just two factors: the automatic stabilisers and slow adjustment to changing circumstances. As shown by Gros et al. (1999, 
p. 34), one can capture over $90 \%$ of the variability of euro zone deficits over the recent decades with a simple regression equation in which the aggregate deficit of the euro zone as a percentage of GDP is just a function of real growth of GDP during the same year and the deficit during the preceding year. The regression results suggest that, on average over the last 26 years, euro zone governments have allowed the automatic stabilisers to work. The deficit increased by 0.5 points of GDP for each full percentage point fall in the growth rate. This is almost exactly what one would expect looking only at the ratio of government receipts (and expenditure, see below) to GDP which is equal to 0.45 in the Euro- 11 countries. Moreover, there seems to be considerable sluggishness in the adjustment of fiscal policy. Only $40 \%$ of the adjustment to the new equilibrium takes place immediately. A report by the services of the Commission (see Buti, Sapir (1998)) also found that the gap between actual and potential output is also not strongly correlated with deficits.

The pre-Maastricht pattern of fiscal policy is clearly not sustainable because it implied an average deficit of over $4 \%$ of GDP. The estimated equation suggests that even if real GDP growth were to stay at $3 \%$ p.a., the deficit would still settle at a value above $3 \%$ of GDP. It is apparent that the sanctions foreseen in the Stability and Growth Pact (SGP) would then quickly have to be applied in reality. ${ }^{5}$ Even if the average deficit is only close to the $3 \%$ limit, there would be problems given that within the average there will always be some countries with higher values. A continuation of the old pattern is clearly incompatible with the Stability and Growth Pact (Gros et al. (1999), S. 34).

However, what needs to changed are not the automatic stabilisers, nor necessarily the habit of slow adjustment, but rather the deficit at normal growth (technically speaking, the intercept of the estimated equation). Not surprisingly, the equation estimated up to 1995 does not work well for 1996 and 1997; it predicts a deficit about $1.5 \%$ of GDP higher than the outcome (2.6\% of GDP). This might be a useful estimate of the impact of Maastricht on fiscal policy so far. Is this enough? Before we answer this question, we observe that the adjustment that was undertaken in 1996 and 1997 seems not to have continued into 1998. The equation predicts that if this adjustment had been permanent, the outcome for

\footnotetext{
${ }^{5}$ The Pact for Stability and Growth contains some secondary EU legislation that will speed up different steps in the excessive deficit procedure. The excessive deficit procedure is contained in Article 104c of the Maastricht treaty which states that EMU member states shall in the long run avoid excessive deficits and describes elaborate provisions of what happens if a member state fails to follow this promise. See Gros, Thgesen (1998), pp. $341 \mathrm{ff}$
} 
1998 should have been a deficit of $1.5 \%$ of GDP instead of the actual value of about $2.60 \%$. This is a first indication that the adjustment towards stable finances that was induced by the desire to participate in the start of EMU has already slipped. Gros et al. (1999), Box 7, pp. 35, provide further analytical material on what one would expect from fiscal policy if it followed the old pattern and what would be needed to keep deficits clear off the Maastricht limit.

A first indication of what is needed call be obtained by, asking what the equation estimated by Gros et al. (1999), Box 7, would predict under the pattern estimated for the pre-Maastricht period, but if growth were to stay at a reasonable $2.5 \%$ p.a. The result is that even under such a "balanced growth" scenario, deficits would quickly hit the 3\% of GDP ceiling and surpass it.

In order to see what would happen if the Maastricht adjustment were permanent (but the automatic stabilisers are allowed to work as usual and the slow adjustment also continues), Gros et al. (1999) also calculated what the equation predicts for the future. Starting from the actual value for 1998, they did this for two scenarios: first, growth is constant and equal to potential, namely $2.5 \%$ (balanced growth) and second, growth drops quickly and even becomes slightly negative as ill 1993, but then recuperates (recession).

The outcome can be viewed in panels A and B of Gros et al. (1999), pp. 36 f., which show the actual deficits of the Euro-11 until 1998, and the projected evolution under scenarios mentioned so far: Under the pre-Maastricht pattern it is apparent that there would soon be excessive deficits, if Euroland were to suffer a recession. The deficits would quickly become as severe as in 1995. Under the post-Maastricht pattern, the deficit would slowly approach zero so that this would appear to be compatible with the Stability Pact. It is thus apparent that under balanced growth there should be no problem. But a recession would quickly lead close to the $3 \%$ limit. Since this equation refers to the average, this would imply, as argued above, that the deficit of some individual countries would be likely to exceed the limit even in the absence of a severe recession. The adjustment that has taken place so far has thus failed to make fiscal policy recession-proof, although the difficulties would be only temporary. A further reason why the adjustment so far is not satisfactory is that debt-to-GDP ratios are not declining substantially in most countries as mentioned above. The average debt-to-GDP-ratio of the euro area has been only stabilised at a high level. From a macroeconomic point of view, there is also no particular reason to run substantial fiscal deficits at this point (Gros et al. (1999), pp. 35 ff.). Thus, one important ingredient of an appropriate 
and sustainable macroeconomic policy mix for Euroland almost certainly should be a restrictive fiscal policy stance.

\section{B. The Alternative to the Pre-Maastricht Pattern: a Different Monetary/ Fiscal Policy Mix}

The results so far suggest that a further adjustment in fiscal policy is desirable to make up for the slippage of 1998 when a rather favourable growth environment was not used to cut structural deficits. A further reduction in structural deficits of about $1 \%$ would also be required to ensure that the automatic stabilisers can work in a mild recession without getting into conflict with the Stability and Growth Pact (Belke, Gros (1998), Buiter (1999), p. 25, Gros et al. (1999), p. 37). Moreover, to the extent that the deficit reduction is achieved through spending cuts (and ceteris paribus leads to lower interest rates), this will also increase future supply because it tends to lower interest rates and will allow governments in future to reduce taxes and supply-side distortions. The latter are potential incentives for national governments to agree to the policy mix proposed here.

One way to illustrate the proposed policy mix is to use the aggregate supplyaggregate demand framework. If the impact on demand of the fiscal contraction and the monetary easing are of the same magnitude, this combination should leave aggregate demand unchanged and thereby also have no impact on inflation. It would thus be perfectly compatible with the task of the ECB to preserve price stability.

One objection to our proposed mix might be that nominal short- and long-term interest rates were at the end of 1998 at near-record lows so that there might not be enough room down. But what matters for demand are real interest rates and inflation is also close to a historical low so that real interest rates are not far from longer-run averages (CEPR (1999a), Gros et al. (1999), p. 38). Figure 6 in Gros et al. (1999), p. 39, shows nominal short-term and long-term interest rates as well as the real long-term rate for the Euro-11 area. It is apparent that while nominal short- and long-term rates were at the beginning of 1999 clearly extremely low by the standard of recent experience, this is not the case for real long-term rates which are now not much below the value already reached in 1993. If inflation declines further - as widely predicted - real rates might actually increase if nominal rates stay constant. One must thus also judge policy with respect to this implicit tightening that might come about in the absence of specific action by the ECB. A related argument against a monetary easing is that the economy would quickly run 
into a liquidity trap at low interest rates, in the sense that all increase in the money supply would not have any effect on demand because the interest rate could not fall below zero. It can be argued however, that this should not be a concern. As long as interest rates are positive, they can still be reduced. Moreover, if this were to happen, price stability would not be endangered in any event. ${ }^{6}$

So far fiscal policy has been specified in this paper in terms of structural or cyclically adjusted deficits. A similar qualification should also apply to monetary policy. ${ }^{7}$ It would be misleading to characterise central bank behaviour as simply keeping the interest rate constant or achieving a predetermined growth rate of the money supply. In reality, central banks adjust the short-term interest rate (the only variable they directly control) systematically in response to current inflation and growth according to a modified form of the so-called Taylor rule. Recent research (Clarida, Gali, Gertler (1998)) has shown that a variant of this rule describes surprisingly well not only the behaviour of the US Federal Reserve, as one would expect, but also that of the Bundesbank. One would thus expect that the ECB will follow a similar rule. Gros et al. (1999), pp. 40 ff., convey a detailed exposition of the reasons why even a monetarist central bank will adjust interest rates in response to output. If one applies such a rule of thumb to current data, it would not imply an immediate need for a cut in interest rates. But a cut might become appropriate once the fiscal adjustment Gros et al. (1999) recommend has taken place.

Gros et al. (1999) just want to make a simple practical point: Monetarism - by which we mean a policy based on the Bundesbank's P-star model - and the Taylor rule (under which central banks adjust interest rates to inflation and the output gap) have very similar implications for the response of short-term interest rates to prices and the output gap. That monetarism and the Taylor rule can be "observationally equivalent" should not come as a surprise since money demand is a function of income. But the second finding is more surprising: for realistic parameter values, monetarism results in a stronger response of interest rates to the

\footnotetext{
${ }^{6}$ Does zero really constitute the lower bound for interest rates? The experience of Japan shows that under extreme circumstances they can even go slightly below zero as savers value the security of savings deposits over keeping large amounts of cash at home. This experience seems to contradict the argument that transaction costs would imply that the lower bound for interest rates is above zero.

${ }^{7}$ One can conceive of monetary policy in different ways. The model used by the Commission services defines an expansionary monetary policy as an increase in the monetary growth rate. The higher inflation that would result from this policy is anticipated by the markets and implies with forwardlooking expectations an immediate increase in (nominal) interest rates. The policy would nevertheless have a temporary positive impact on domestic demand as real interest rates would still fall (a little) because the increase in the nominal interest rate is smaller than the increase in inflation. This is not the policy Gros et al. (1999) advocate.
} 
output gap than suggested by the Taylor rule in its original formulation.

The so-called $P$-star model of money and prices is a convenient framework for discussing the analogies between monetary, targeting and the Taylor rule. Based on the quantity equation of money, the P-star model derives the "price gap" or the deviation of prices from their long-run equilibrium, given by:

$$
p^{*}-p=\left(y-y^{*}\right)+\left(v^{*}-v\right)
$$

where $P$ is the price level, $y$ is output, and $\mathrm{v}$ is the velocity of money. Starred variables denote long-run equilibrium levels and all variables are in logs. Longrun prices $p^{*}$ are defined by output and velocity at trend, and a fixed money supply controlled by the central bank. Prices will be temporarily above their longrun equilibrium whenever output is below trend or velocity is above trend.

How do we translate this model of inflation into Taylor rule terms? We know that velocity is typically increasing in nominal interest rates (because of a higher opportunity cost of holding money) and real output (because of a higher number of transactions and because higher income is usually perceived also to correspond to higher wealth). Assuming the relationship to be linear in logarithms, we can express the "velocity gap" by:

$$
\left(v^{*}-v\right)=b_{1}\left(i^{*}-i\right)+b_{2}\left(y^{*}-y\right),
$$

where $i$ is the interest rate and $i^{*}$ is the equilibrium interest rate that obtains if output, velocity, and inflation are at their equilibrium levels. Substituting (2) into (1) implies:

$$
\left.i=i^{*}+\left(1 / b_{1}\right)\left(p-p^{*}\right)+\left(1-b_{2}\right) / b_{1}\right)\left(y^{*}-y\right) .
$$

Thus, given that the long-run price level is anchored by $p^{*}$, interest rates exceed their equilibrium level whenever prices are high and/or output is high. The intuition is that with a fixed money supply, a higher price level is accompanied by higher interest rates because it reduces the real money supply. Likewise, higher output is accompanied by higher interest rates because it increases real money demand. A broader discussion of these issues can be found in Taylor (1998), Hatzius, Mayer (1998) and Mayer (1999).

How large are the coefficients in equation (3)? To answer this, an estimate is needed of the short-run response of velocity to nominal interest rates and real output. Hatzius, Mayer (1998) find, on the basis of evidence from Germany and the large EMU5, that it would be reasonable to assume that both the coefficients 
$b_{1}$ and $b_{2}$ take values of around 0.5. Equation (3) then becomes:

$$
i=i^{*}+2\left(p-p^{*}\right)+\left(y-y^{*}\right) .
$$

Equation (4) is similar to the well-known Taylor rule which says that nominal interest rates should be set according to:

$$
i=i^{*}+1.5\left(d p-d p^{*}\right)+0.5\left(y-y^{*}\right),
$$

where $d p$ is year-on-year inflation and $d p^{*}$ is the inflation target (recall that in our notation $i^{*}$ is the equilibrium real rate plus the inflation target). To simplify matters, we call equation (4) the monetarist Taylor rule and equation (5) the Keynesian Taylor rule. They differ in two respects. First, the price level rather than its rate of change enters the monetarist Taylor rule. Second, the coefficient of the output gap is larger in the monetarist Taylor rule (at least given our empirical results of the determinants of velocity).

What do these differences mean? The first does not have important implications since by measuring the deviations around an index value of 100 deviations, the difference in the price level in equation (4) is equivalent to the inflation rate in equation (5). But the second difference is important and surprising: the higher output coefficient in (4) means that a monetarist central bank will - when viewed in interest rate terms - move more aggressively, to eliminate in output gap. This is an intriguing result. The reason is that the output gap is a very powerful predictor of future inflation pressures, and smoothing output by more than in the original Taylor rule delivers better results in terms of both output and inflation variability.

What does this result imply for Euroland's interest rates? The output gap for Euroland is expected to widen slightly to about $1.8 \%$ of GDP in 1999, and inflation should remain subdued at 1.3\%. Assuming that the ECB's stated goal of inflation "below 2\%" translates into an inflation target of $1.5 \%$ and that the equilibrium real short rate is $3.6 \%$, the Taylor Rule in its original form implies a short-term interest rate of $3.9 \%(=3.6+1.5+1.5(1.3-1.5)-0.5(1.8))$, while the Taylor rule with an output coefficient of one implies a rate of $3 \%(=3.6+1.5+1.5$ $(1.3-1.5)-1.8)$ - exactly the rate on which Euroland's central bankers settled in early December. Further adjustment in fiscal policy should lead to a reduction in the equilibrium real interest rate. A fiscal adjustment would thus justify even lower interest rates!

The main concern is that in the absence of co-ordination between monetary and fiscal authorities, the preferred policy package will not come about. The time 
needed for an interest rate cut to exert its effects on demand might be longer than that for fiscal policy. Hence, the fiscal authorities might want to wait for monetary policy to move first. The ECB might also not want to move first because it might not receive a clear signal from the fiscal authorities. But if finance ministers were to abandon the line currently being taken in some member countries -that they would like to apply a straight short-term fiscal stimulus - and instead give a clear signal that they will reduce structural deficits, the ECB should be willing to act and should signal its willingness to do so (Emerson (1999), p. 46, Gros et al. (1999), p. 42).

\section{The Euro in the Global Economy: Implications for the Policy Mix}

The euro zone is a relatively closed economy in the sense that exports account for only about $11 \%$ of its GDP (a similar level as for the US and Japan), but the European economy can nevertheless be strongly affected by international developments because of financial market linkages and because exports can be so volatile that they can have an important impact on demand. Another reason why policy-makers in Europe should pay attention to global developments is that the euro will instantly become a global currency in the sense that all over the world both borrowers and investors will like to use the euro. This does not mean that the demand for euros suddenly increases, but both the supply of and demand for assets denominated in euro will increase. Shifts in the preferences of investors are sometimes very large and sudden. Large sudden portfolio shifts from the dollar into the euro are therefore a distinct possibility.

While the relatively low degree of openness of Euroland would suggest that the exchange rate of the euro should not be important, the major macroeconomic models predict that changes in the dollar/euro rate call have strong effects on the economics on both sides of the Atlantic. For example, the MF (1998) reports that a 15\% appreciation of the US dollar induced by a shift in portfolio preferences towards US (or rather dollar-denominated) securities would lead to an increase in European GDP of close to 1 full percentage point and would have negative impact on the US of a similar size. Most of the impact on the level of demand disappears after two years, however, so that the effects in terms of growth rates becomes strongly negative starting in year two. Simulations with other models yield qualitatively similar results regarding demand. taken at face value, the models thus suggest that any shift in portfolio preferences away from the dollar and towards the euro, which would result in a substantial appreciation or the euro, should for 
two years reduce growth in Euroland considerably and be a strong stimulus for the US economy. The cost for Europe and the benefit for the US would, however, be limited. ${ }^{8}$

One consequence of the policy mix proposed here (tight fiscal, loose money) would ceteris paribus be a weaker exchange rate of the euro and a larger current account surplus of Euroland. It could be argued that this is not desirable from a global point of view in the light of the bulging US current account deficit and the need of the Asian countries in crisis to achieve large surpluses. Until recently, it was generally assumed that Euroland would have a current account surplus of about 1.5\% of GDP in both 1998 and 1999, and an increase in this surplus might not be appropriate from a global point of view. However, newer data suggest that the surplus of the EU in general (and also that of the Euro-11) has been considerably overestimated. We do not want to over-emphasise these facts since current account deficits should generally not be a policy target, but the new data are nevertheless interesting.

Since the establishment of the Single Market, customs controls were abolished for intra-EU trade in 1993. This led Eurostat, the EU statistical office, to introduce a new system for recording intra-EU trade flows, based directly on companies' declarations of their import-export activity. The concepts of "arrivals" and "dispatches" are used for intra-EU trade, but given that the former is declared CIF and the latter FOB, a divergence always exists between the two values, which amounted in 1997 to 60 billion ecu (about 5.5\% of intra-EU trade or 1\% of Euroland's GDP). Taking into account other less important statistical problems, the best available estimates of the external trade of Euroland yield a total estimate for the current account of the Euro-11 zone equivalent to about $0.2 \%$ of GDP. i.e. close to zero. This means that a weaker exchange rate of the euro and a larger current account surplus of Euroland as a consequence of the policy mix proposed here (tight fiscal, loose money) would be less of a drawback than estimated above.

Moreover, a misguided attempt to make a counter-cyclical budgetary policy could lead to an excessive growth of public deficits (in fact, the opposite of the

\footnotetext{
${ }^{8}$ Levin, Rogers, Tryon (1997) add, somewhat surprisingly, that the current account of the euro area is not strongly affected by a dollar depreciation, whereas that of the US improves significantly, mostly at the expense of Japan and emerging economies. The impact on the current account of Euroland would be limited because the impact of substantial changes in the volume of exports would be offset by changes in relative prices as US exports become relatively cheaper. This pattern seems to be confirmed by recent developments. The current account of the US has deteriorated and thus provided the counterpart to the increasing surpluses in Asia whereas the surplus of the euro area has not been affected. Most forecasts concur that in the absence of corrective policy actions, this pattern is likely to continue.
} 
policy mix proposed in this paper, see section III.A) and hence to increases in interest rates. This might even trigger an overshooting appreciation of the euro against the dollar. A resulting movement of long-term interest rate differentials relative in favour of the euro could push portfolio investors into in a speculative band wagon. The proposed policy mix of fiscal rigour and monetary ease is also corroborated from this point of view (see Emerson (1999), p. 44).

The results by the IMF (1998) imply that swings on the order of $10-20 \%$, as recently experienced in the dollar/DM and dollar/yen rates, can have considerable short-run economic costs even among relatively closed economies such as Euroland, the US and Japan. This implies that it would be desirable to contain fluctuations in exchange rates among the G-3. From this point of view, the recent proposal formulated by the new German Minister of Finance has an economic justification. The problem with the target zone idea is that it is so difficult to implement in practice because it would require that international consideration would have to dominate domestic priorities in setting economic policy. Since fiscal policy does not seem to be a potent weapon to offset the spill-over effects of exchange rate swings caused by portfolio shifts, the only way target zones could be maintained would be if monetary policy is geared towards external considerations. Moreover, any implementation of G-3 target zones would have to deal with the so-called " $\mathrm{N}$ minus one" problem, familiar to Europeans from the history of the EMS. In a system comprising three countries, there are only two independent exchange rates, the third degree of freedom consists of the average level of interest rates. Who would determine this fundamental policy choice?

The only practical solution at present appears to be that one should look out for signs of shifts in portfolio preferences towards the euro. For example, it appears that Japanese insurance companies are shifting a significant part of their portfolio towards the euro because they anticipate that the Euroland capital market will be much more liquid than were its constituent national markets in the past. Should signs such as these multiply and be accompanied by a substantial and unwarranted strengthening of the euro, the appropriate reaction would be to satisfy the increased demand of the rest of the world for assets denominated in euro. This constitutes another reason why the ECB should be able to carefully analyse developments in financial markets. If enough borrowers also switch to the euro, the private sector might be able to satisfy the increased demand at a reasonable stable exchange rate. But experience has shown that portfolio preferences can change so quickly that this is not always possible. 
To summarise: complacency about the global environment is not warranted. Portfolio shifts towards the euro could lead to a significant negative contribution from external demand for Euroland if they lead to an exccssive appreciation. But portfolio shifts towards the euro could also present an opportunity because they imply, ceteris paribus, that foreigners are more willing to hold euro assets and could thus be an occasion to achieve even lower interest rates in Euroland.

\section{Coping with Country-specific Features in Euroland: No Role for Fiscal Policy}

We do not expect many problems to arise from fundamental differences in economic structures among member states. It is not widely appreciated that within the Euro-11 area the dispersion in indicators such as GDP per capita is smaller than in the US We realise that GDP per capita is not the best indicator for differences in economic structure, but as it is often used as an overall measure, we want to attract attention to the fact that the dispersion among the Euro-11 is rather low, compared to that in federal states such as the US or Germany (see Gros et al. (1999), Table 4, p. 45). This does not imply that Euroland will not face serious problems arising from differences in economic conditions across member states, but the problems might come from quite different sources than usually assumed. For instance, some countries might enter EMU with a divergent business cycle. Ireland as one of current EMU 'hotspot' economies seems to be the prototype of this case as it has been growing at the start of EMU at over $8 \%$ which is over twice the Euroland average of between 2 and $3 \%$.

A key issue in this, and other possible cases of differences in economic conditions within Euroland, is whether domestic prices should be allowed to constitute the main adjustment mechanism. We would argue that given the low degree of labour mobility in Europe, domestic prices and wages must be allowed to adjust to shocks or differences in the business cycle. Ireland is the best example of divergence as EMU membership requires a reduction in Irish interest rates of about 3 percentage points, which might lead to an overheating of the economy. As inflation has already exceeded $3 \%$ in 1998, there seems to be a considerable risk to price stability in that country.

Nevertheless, the position of Ireland relative to the business cycle in the rest of Euroland will change over time. This implies that the de-synchronisation that Ireland is experiencing should be temporary and that the inflation differential should disappear over time. The increase in the Irish price level that takes place 
would lend to dampen Irish exports so that demand would be reduced over time until the differential in demand pressures disappears. Within EMU a price level adjustment should thus be viewed as a normal adjustment channel that should be allowed to work because this is the channel through which relative prices can change. The extent to which the domestic price level has to adjust will depend on the degree of openness which determines the size of the real appreciation that might be required to re-establish equilibrium for domestic goods and the elasticity of demand to the real interest rate. Since the Irish economy is very open (intra-EU exports of goods amount to almost one-half of GDP), the domestic price level will not need to increase much to restore equilibrium.

The conventional advice to the Irish government is to use fiscal policy contraction to offset the monetary easing that comes with EMU (Belke (1998), Belke, Gros (1998)). We have argued that this prescription is wrong because prices should be allowed to become the main adjustment mechanism within EMU. This point of view is reinforced in the case of Ireland by the fact that using fiscal policy to control deviations of the national business cycle from the Euroland average simply might not work. Simulations with the QUEST model of the EC Commission suggest that for small open economics, the (impact) multiplier of fiscal policy is close to zero. If there are no systematic differences in the slope of the supply curve across countries, this implies that the impact of fiscal contraction on prices will also be minimal in the case or such an open economy as Ireland's. Thus, the Irish authorities seem to have no other choice, but "to let it rip" - for the time being. ${ }^{9}$

\footnotetext{
${ }^{9}$ Adjustment via movements in domestic prices is of course not free of its own problems. The unavoidable slowdown that is induced by the increase in the price level of Ireland relative to Euroland might lead to a recession or difficulties in financial markets. As economic agents should realise by now that the adjustment has to come sooner or later, there is no a priori reason to believe that there should be serious problems down the road. However, the experience with the end of periods of strong growth has shown that a financial market bust often follows the previous boom and exacerbates the downturn. Are there reasons to believe that this will be the case in Ireland as well? The usual mechanism through which a financial market bust arises and creates problems is that banks over-lend when asset prices are high and have to reduce credit to everybody when asset prices go down. The problem could thus come from asset markets. As equity markets will operate at the scale of Euroland, the main problem is likely to come from the real estate market. Housing prices have already grown considerably in Ireland over the last years and there are indications that some banks are willing to provide mortgages for over $100 \%$ of the present value of houses because they assume that they will be covered by future price increases. This implies that once housing prices fall, a number of mortgages might no longer be adequately collateralised and become a source of heavy losses. This happened in Japan after the boom of the late 80s and is happening to some extent in Eastern Germany at present. Tight prudential supervision is thus important in order to avoid systemic problems with the Irish banking system at a later stage. See Gros et al. (1999), pp. $46 \mathrm{ff}$.
} 
The reason for this result can be illustrated if one plots openness (the ratio of intra-EU imports to GDP) against the fiscal policy multiplier (as estimated by the QUEST model of the Commission). There is clearly a tight correlation between openness and the effectiveness of' national fiscal policy to affect domestic conditions. Only less open economics such as Spain can influence domestic prices with national fiscal policy (see Gros et al. (1999), Figure 7, p. 47). ${ }^{10}$

\section{Getting the Policy Mix Right: The Role of the Euro-11}

\section{A. Explanations and Further Recommendations}

Our main conclusion regarding the policy mix - tighter fiscal but looser money - might be difficult to implement because, in contrast to monetary policy, fiscal policy is not set at the European level. The formulation of - and political responsibility for - fiscal policy remains firmly at the national level even under EMU (although there is much more convergence pressure of EMU on fiscal policies than, e.g., on employment policies, see Institut für Arbeitsmarkt- und Berufsforschung (1999)). This raises the issue of how to co-ordinate monetary and fiscal policy at the European level. Getting the fiscal-monetary mix right might be difficult for Euroland. Given the asymmetry in the set-up for monetary and fiscal policy, an important question is whether one could achieve the appropriate policy mix without any explicit co-ordination of national fiscal policies through a European institution. We would argue that explicit co-ordination is important on two accounts.

First of all, in the absence of co-ordination between monetary and fiscal authorities a sensible policy package might not come about at all or this package is not adjusted properly around the cycle (Demertzis, Hughes Hallett, Viegi (1999), p. 6, Gros et al. (1999),p. 48). Of course, it is likely that the ECB will react to a fiscal tightening even without any explicit co-ordination agreement. But both fiscal and monetary policy operate with some time lags. If fiscal policy were to move first, it would take some time before the effects are felt; and if the ECB reacts only then, the effects of a lower interest rate would be felt even later. This is especially true if the time needed for an interest rate cut to exert its effects on demand might be longer than that for fiscal policy, the political cost of a first move

\footnotetext{
${ }^{10}$ For the related question whether a co-ordination of wage bargaining systems across Euroland makes sense see Soskice, Iversen (1998).
} 
by fiscal policy might be rather high. The fiscal authorities might therefore want to wait for monetary policy to move first. But the ECB might also not want to move first in the absence of a clear signal from the fiscal authorities. If fiscal policy is tightened only after monetary policy had its effect, inflationary pressures might emerge in the meantime. Moreover, whoever moves first does not have any guarantee that the other will react in the expected way.

Both time lags and uncertainty therefore provide a reason why co-ordination between monetary and fiscal authorities might be needed. In other words: if one set of policy is dominating the policy setting process by e.g. legal restrictions (here: the ECB statute) or a first mover advantage in decision making (as indicated above), the policy mix will be selected as to suit the interests of the dominating policy (in the case of EMU: monetary policy whose primary target is price stability) best. As a reaction, other policy makers (here: national fiscal policy) normally tend to retaliate and turn the policy mix back in their direction (towards a higher priority of growth and employment). By this, the credibility and the effectiveness of the dominant policy maker (here: of the ECB) might be hampered.

A recent investigation by Demertzis, Hughes Hallett, Viegi (1999) points out exactly this line of reasoning. In their view, the shaping of an autonomous Central Bank dichotomises policy making. Giving autonomy to the Central Bank grants governments a more important role via fiscal policies. Demertzis, Hughes Hallett, Viegi (1999) are able to show on the basis of a game-theoretic model in the tradition of Alesina, Gatti (1995) that monetary independence (the more so if this is coupled with increasing conservativeness of the Bank) creates a surrounding in which more liberal (socialist) policies tend to be elected. As a consequence, fiscal policy which will still be in the hands of elected governments will as a rule tend to conflict with monetary policy. ${ }^{11}$ And this is exactly what one finds empirically. Campillo, Miron (1997) are able to demonstrate that net of other factors like above all fiscal policies independent central banks have not in every case provided lower inflation. In addition, Mélitz (1997) refers to the fact that fiscal and monetary policy have generally moved in opposite directions in all OECD economies including those with the most conservative central banks.

This dichotomy described above leads to a greater probability of conflict between the monetary and fiscal policy authorities. At the same time co-operation

\footnotetext{
${ }^{11}$ Since such conflicts let one policy to neutralise the policy of the other, both parties will less probably reach their specific goals.
} 
between them becomes more difficult. The other side of the same coin is that it is also more important for both to co-operate. The way out of this problem clearly is to avoid policy conflicts. "Hence the question is not whether the bank will be exposed to political pressures - it will be. The question is whether there will be a framework which can contain those pressures" (Demertzis, Hughes Hallett, Viegi (1999), p. 32). The first strategic option available (and because of its second-best character only a partial remedy, see Kollintzas, Philippopoulos, Vassilatos (1999)) is to ex ante restrict either the fiscal or the monetary interventions. The former of these is the approach of the EMU's Stability Pact which resembles the Clinton-Greenspan policy mix (fiscal rigour with monetary ease). The latter corresponds to the policy regimes of the 70s and 80s, especially the Reagan-Volcker mix (fiscal ease with monetary rigour). ${ }^{12}$ The second strategic option would be to make use of a coordinating mechanism between fiscal and monetary policies, i.e. a bargain between two freely contracting players. In view of the above cited results by Campillo, Miron (1997) and Mélitz (1997), this could be seen as a viable strategy for EMU insofar as there are strong indications that there has already been a significant de facto coordination of fiscal and monetary policies in the participating countries. Obviously, there has in the past existed a desire among policy makers to avoid an open conflict between them (Demertzis, Hughes Hallett, Viegi (1999), p. 11).

There is increasing evidence that the German Bundesbank has in the past found it necessary to co-ordinate informally with both government and unions in order to avoid policy conflicts (see in detail von Hagen (1998), Posen (1997) and Demertzis, Hughes Hallett, Viegi (1999)). ${ }^{13}$ Seen on the whole, one could in the light of the above arguments argue that the ECB could do the same as the Bundesbank. However, it has to be noted that such bargains between the ECB and fiscal policy are explicitly ruled out by the Maastricht treaty, i.e. by a different constitutional position of the ECB as compared with the German Bundesbank. In that sense one might argue that the macroeconomic policy mix in EMU is already fixed by the Maastricht treaty and the discussion about it would be obsolete ex ante (Bogai (1999), p. 560, Kotz (1998)). The ECB is -according to the wording

\footnotetext{
${ }^{12}$ For these interpretations see Demertzis, Hughes Hallett, Viegi (1999), p. 12, Emerson (1999), p. 43, and Kotz (1998), p. 124 f.

${ }^{13}$ Just to give some examples: the German 'Konjunkturrat' and the 'Finanzplanungsrat' (StabWG 1967) both include members of the Bundesbank. One important reason for the Bundesbank to allow for the balance of two targets and, thus, suitable shifts in the policy mix is that the Bundesbank had for a long time of its existence to be aware of the fact that its independence could be eliminated by a simple vote in the Bundestag.
} 
of the Maastricht treaty- not allowed to take instructions from national governments, i.e. from those who are hit by a lack of accountability of the ECB and theoretically capable of amending the bank's statutes, targets or operating rules. ${ }^{14}$ Moreover, there is up to now no distinct mechanism available by which the ECB would be able to co-ordinate with the national fiscal authorities.

We therefore argue that finance ministers should abandon the ideas currently favoured in some member countries, namely to apply a straight short-term fiscal stimulus. What is needed instead is a clear signal that structural deficits will be reduced if the ECB adjusts monetary policy appropriately. In response, the ECB should be willing to act and should signal its willingness to do so. Action to cope with an unexpected downturn for example will therefore have to be taken by the only player in Europe “ ... which has both bow and violin: the ECB” (Buiter (1999), p. 25).

A second, related reason for the need for co-ordination at the European level is that individual national finance ministers cannot conclude deals with the supranational ECB. ${ }^{15}$ Fiscal-monetary policy co-ordination at the euro-zone level requires an institution that can represent fiscal policy vis-à-vis the ECB. The only institution that could achieve this is the Council of Finance Ministers (called usually ECOFIN). This body also implements the Maastricht provisions concerning excessive deficits as detailed in the Stability and Growth Pact. In the context of its regular work programme, ECOFIN also receives presentations by EMU member countries of their so-called convergence programmes, in which they outline, ex ante, their medium-term fiscal policy strategy. These programmes should be co-ordinated so that a clear overall policy line emerges. The Council of Finance Ministers deliberates mostly with all 15 member states present, but some decisions are taken only by an innerclub of the 11 member countries of Euroland. This restrictive group, the so-called Euro-11, also has a more direct interest in getting the policy mix right for Euroland. The purpose of the Euro-11 Council should thus be to co-ordinate a strong message from national finance ministers about the aggregate fiscal policy stance. If it achieves this, it should also be taken seriously by the ECB. It would be useful for the Euro-11 Council to concentrate

\footnotetext{
${ }^{14}$ See Padoa-Schioppa (2000), pp. 7 ff., and Randzio-Plath (2000). In contrast, the ECB is only accountable to the European Parliament, i.e. to those who cannot change its statutes and procedures. However, according to Kotz (1998) a need for co-ordination of monetary and fiscal policy cannot be excluded ex-ante: "Die Debatte über die Stabilisierungsrolle der öffentlichen Haushalte und deren Zusammenspiel mit den weiteren wirtschaftspolitischen Akteuren wird sich nicht mit Verweis auf Maastricht, Stabilitätspakt etc. dauerhaft ruhigstellen lassen".

${ }^{15}$ For the following proposal see Gros et al. (1999), pp. $48 \mathrm{ff}$.
} 
on the aggregate policy stance and not to get diverted into discussions about the effects individual national fiscal policies could have within the euro zone because the spill-over effects of national fiscal policy are actually not important as shown among others by Gros et al. (1999) and Welsch (1998). The last important aspect deserves to be investigated closer in the following.

It is widely assumed that the need for fiscal policy co-ordination increases as exchange rates are fixed. This is not necessarily the case, however. From a strict economic point of view, the case for fiscal policy co-ordination rests on the idea that fiscal policy has spill-over effects. If any one country, say Germany, stimulates demand through a fiscal expansion, its partners in the EU, say France, benefit from higher demand for their goods as well. But within the euro area this positive spill-over effect is offset by another effect. Stronger demand in any one country puts pressure on interest rates and thus leads to higher rates for the entire area. Germany's partners will thus feel two effects from a German fiscal expansion: increased demand for their exports and a rise in the euro interest rate which would dampen demand. Which of these two effects is stronger is impossible to determine a priori. Numerous simulations with large-scale macroeconomic models have come to the conclusion that these spill-overs are likely to be insignificantly small; whether they are positive or negative cannot really be determined with any precision. This implies that there is not a strong economic argument for fiscal policy co-ordination. The average policy stance could be appropriate even if all member countries set their policy independently. Fiscal policy should remain a national prerogative and should only be responsible for providing public goods in a sustainable fashion, see Bogai (1999), p. 560, and Sachverständigenrat (1998)). ${ }^{16}$

A however defined co-ordination between monetary and fiscal policies (and often connected with that the 'gouvernement économique') in Euroland after all experience constitutes a problem for some and especially for the 'Germano-Dutch wing' (Buiter (1999), p. 24, Kotz (1998), pp. 126 f.) in the ECB. ${ }^{17}$ According to

\footnotetext{
${ }^{16}$ The spill-over effects of fiscal policy can be even greater outside EMU. For example, a fiscal expansion in the UK is likely to have a stronger impact on demand in France and Germany than an equivalent move by Italy. This is because a fiscal expansion by the UK would appreciate the pound and thus increase UK demand for imports from the euro area, including France and Germany. By contrast, a fiscal expansion by Italy would have no exchange rate effect inside the euro area. but would just exert upward pressures on interest rates.

${ }^{17}$ See Kösters, Kotz (1999) and Kotz (1998) for a debate on (German versus French) representative views on and expectations about EMU. Similar concerns were expressed by some participants in the EuroBriefing, 4 November, Brussels.
} 
Buiter (1999) and others, the latter tends to interpret the Euro-11 as an attempt to undermine the operational independence of the central bank. Although this caveat cannot be dismissed entirely, one should at the same time take into account that independent agents can opt for co-ordination of their actions and, by this, internalise net gains, even when the co-operating parties have different goals (on that topic see extensively Demertzis, Hughes Hallett, Viegi (1999)).

However, getting the balance between monetary and fiscal policy right is as much an important logistical challenge as a political problem. This is especially valid if co-ordination (including adequate institutional arrangements and practices) is strived for between the ECB and the eleven national finance ministers (Buiter (1999), p. 24). Moreover, it cannot be excluded that parts of communication problems between EMU-countries which arise when the adequate policy mix has to be determined are caused by nation specific perceptions of the true model of the functioning of EMU. The agreed policy mix (institutions versus competition) is a function of the different 'believe'-structures with respect to, e.g. adjustment costs (Franckel, Rockett (1988), Gretschmann (1999)). While a majority of analysts concludes that European unemployment is the unavoidable result of a wide array of rigidities, a competing view stresses substantial output gaps and derives ample room for more expansionary fiscal and monetary policies. Both views, the new-classical policy ineffectiveness proposition and the Keynesian non-market-clearing diagnosis, appear to be shared contingent on national background characteristics (Hardes (1999), p. 208). Since there is obviously a consensus lacking among the separate economic policy actors in Euroland, an emphasis on co-ordination between fiscal and monetary policy appears to be rather ambitious. However, it would be at the same time be very unrealistic to conclude that the process of institution-building has ended with the Maastricht treaty (Kösters, Kotz (1999)). Euroland as an open evolutionary arrangement might give some room even for co-ordination efforts.

\section{B. Uncertainties Connected with the Proposed Policy Mix}

The core incentive problem with the proposal by Demertzis, Hughes Hallett, Viegi (1999) and Gros et al. (1999) of co-ordination of monetary and fiscal policy is: why should fiscal policy inescapably be restrictive if there is monetary policy ease? The answer of the above authors would probably be that the interest rate channel itself (here: lower interest rates which should make a Pareto-efficient solution possible) could solve this incentive problem. With respect to this, one 
should remember that it has been shown in section IV.A within the Taylor-rule framework that a further adjustment in fiscal policy should lead to a reduction in the equilibrium real interest rate. A fiscal adjustment would thus justify even lower interest rates on behalf of monetary policy. However, some questions on the validity of the above co-ordination proposal remain.

How can one prevent monetary and fiscal policy from building up an alliance or a collusion against the interest of EMU citizens when both players prefer a 'Verhaltensabstimmung' between themselves? ${ }^{18}$ If one rejects co-ordination between them: which institutional arrangement which does not rely on fiscal policy co-ordination in a narrow sense can guarantee the absence of the above mentioned incentive problems? Is the fixing of the policy mix in Euroland a clear case for co-operation in the sense of a minimal art bilateral information, experimentation and the creation of conceptual guidelines which by itself would have substantial benefits for the ECB? ${ }^{19}$ Why is co-ordination necessarily superior to an assignment solution (Härtel (1999))?

Moreover, some possible caveats with respect to the (within bounds) countercyclical stance of monetary policy have to be at least mentioned here. Whereas the interest rate cut by the ECB on 8 April 1999 has been argumentatively wellfounded in section II, there are also arguments brought forward against it (CEPR (1999a), p. 5). For example, in 1998 interest rates have fallen substantially. If one takes into account that interest changes have their main impacts on the real economy after a period of about 12 to 18 months, a significant monetary expansion was already in the pipeline. This conclusion is strengthened by the facts that a) M3 growth is since some months larger than its reference value of $4.5 \%$ target of the ECB (September 1999: 5.9\%) and b) the euro has depreciated in the first half of 1999 since its launch. In addition, large parts of the slowdown seems to be caused by the Asian crisis of 1997 and reduced exports of the euro area. However, in the meantime there have been clear signs of a recovery of the Asian region. This in turn will tend to stimulate EMU exports. From this perspective, coordination between monetary and fiscal policy might be technically difficult because the distribution of the gains in time and their magnitude might be uncertain.

In the same vein, the interest cut tended to lead to inflation expectations with the potential to increase long-term interest rates and to lower investment activity. This

\footnotetext{
${ }^{18}$ See for this the corresponding well-known hypotheses by Roland Vaubel.

${ }^{19}$ See Bogai (1999), p. 561, ECB (1999), p. 7, and Kösters, Kotz (1999), p. 8.
} 
is exactly, what one can observe since the second quarter of 1999 (Institute of World Economics (1999)). Emerging inflation will make sharp and costly reversals necessary in the future (see, e.g., the widely anticipated decrease in the interest rate by $0.5 \%$ on 4 November 1999) because inflation is more easily created than suppressed. If such reversals of policy are made frequently the euro exchange rate would fall and flatter. However, another possible caveat against the Greenspan-Clinton policy mix does not apply here. It is often maintained that by the rate cut on 8 April 1999 the ECB had less room for future cuts. Future cuts, however, have not proven to be necessary in the meantime because Euroland's economy tended to recover (see, e.g., Institute of World Economics (1999)). On the contrary, the Taylor-rule (Taylor (1993)) and with some qualifications also the McCallum rule (McCallum (1987)) point towards the necessity of an increase in the interest rate of more than one percentage point until the end of the year 2000 (for details see Institute of World Economics (1999)).

Finally, the issue of a counter-cyclical role of the ECB is complicated by $a$ number of uncertainties respectively imponderables (for the following see, e.g., CEPR (1999)). First, forecasts are subject to uncertainty. Second, inflation reacts with long and variable lags to monetary policy decisions. These lags are all the more uncertain because EMU has a too short history to allow reliable estimates of e.g. the European money demand and the velocity of money. Moreover, the financial structure in Euroland (European banking and its supervisory framework) is evolving. Finally, the consequences of the increasing degree of circulation of electronic cash for the ECB are as yet unclear. It follows that the policy advice given in this paper might be theoretically correct but practically insufficient.

At the end of this section, some remarks with respect to the suitability of the Greenspan-Clinton mix for the current business cycle stance in Euroland seem to be necessary. First, there appears to exist little doubt that a prolonged deterioration of the euro might seriously damage the euro's international role. If Euroland cannot meet US growth performance (as it actually becomes more and more obvious) or if the EU governments would prefer a more loose fiscal policy than the US (i.e., the 'wrong' policy mix according to section IV.A) a depreciation of the euro can indeed be expected. ${ }^{20}$ This, in turn, would make central banks and other third market participants less prepared to substitute euro for dollar. As a

\footnotetext{
${ }^{20}$ See also Emerson (1999), p. 44. Experience with the US-dollar has shown that the relative mix of monetary and fiscal policy in the long-term significantly determines the strength of a currency (Kotz (1998), p. 124 f.).
} 
consequence, the room of the EU to maintain a (actually: slightly) lower interest rate than in the US would be impaired. However, the main reason for relative higher interest rates in the US in 1998/99 was that capacity utilisation and growth were lower in the EU than in the US. If one additionally takes into account that the U.S. savings rate is distinctly lower in the US than in the EU even similar government deficit ratios in the US and Euroland would imply that the EU would run a current account surplus (causing an euro appreciation) while the US would face a current account deficit.

Second, another polito-economic consequence of the current business cycle stance in Euroland vis-à-vis the US deserves attention as well. The current relative business cycle performance might easily let the US enter the policy game as a dominant strategic player. In fact, the US could try to force the EU into a certain policy mix in order to get rid of their current account deficit and their role as a 'Konjunkturlokomotive'. For example, the application of the proposed ClintonGreenspan mix to the EU might contribute under the above described circumstances to a 'soft landing' of the US economy. Whether this will lead to welfare gains or losses, can be left open to further debate (see also section III.D). ${ }^{21}$

Third, it has to be taken into account that the economic environment relevant for the ECB's decisions has changed significantly since 8 April 1999, the date of the most recent interest rate cut. Is the widely anticipated decrease in the interest rate by $0.5 \%$ on 4 November 1999 compatible with the proposal of a policy mix derived in this chapter before? The answer tends to be yes, although authors like Gros et al. (1999) would almost certainly have preferred instead an even more tightening of fiscal policy combined with an unchanged monetary policy stance. ${ }^{22}$ The anticipated step can principally be interpreted as a logical one, if one accepts monetary policy in Euroland being characterised by an active feedback-rule, i.e. monetary policy is within bounds allowed to react to the business cycle stance. ${ }^{23}$ The main reason is that there are clear signs of an economic recovery looming at the horizon with long-term (and more recently also short-term) interest rates increasing strongly.

\footnotetext{
${ }^{21}$ For these arguments see Gretschmann (1999).

${ }^{22}$ The inflation target in the range between 0 to $2 \%$ is consequently regarded by Gros et al. (1999), p. iv, as too low and too narrow. See inter alia the now famous report of Boskin Commission for the U.S. and the different Euroland country studies in the wake of it.

${ }^{23}$ One possible interpretation of the Bundesbank behaviour would be that the Buba also followed a feedback-rule with an escape clause in the sense that its monetary growth target depended on estimations of the potential growth (feedback-rule) and that it explained each deviations (escape clause) of it detailedly.
} 
In the light of the above arguments, the proposed policy mix finds some backing, however, without having solved incentive problems completely and convincingly. Moreover, the ECB should not be blamed for making too large concessions to political pressures in case of its interest rate cut on 8 April 1999.

\section{Summary}

The starting point of this paper was that the new strategic EMU institutional setup can be best characterised as a triangle of co-operation. From this, the question automatically arises what kind of additional co-operation or even co-ordination is necessary and feasible in order to cope with this new EMU institutional set-up. Chapter II started with a brief description of the status-quo of the new policy game under EMU (section II.A) and of the quite undisputed microeconomic policy recommendations for Euroland (section II.B). The respective results served as reference points with respect to the derivation of macroeconomic policy recommendations.

Chapter III set out the position of this paper on details of an appropriate macroeconomic policy in the first year(s) of Euroland. It started in Section III.A by asking what would happen under a business as usual scenario and concludes that the pre-Maastricht pattern of fiscal policy would quickly lead to grave problems. The paper then laid out in section III.B the most promising alternative monetary-fiscal policy mix: a policy mix consisting of a restrictive fiscal policy and a monetary policy which has -within the bounds of price stability- some leeway to act counter-cyclically. The quite successful Clinton-Greenspan policy mix in the US was taken as an example in that respect. It was argued and demonstrated that this kind of policy mix could be compatible and totally in line with monetarism. Even a monetarist central bank will adjust interest rates in response to output. In section III.C it is asked whether global considerations as, e.g., an assessment of the importance of the euro as a foreign reserve currency, would call for a different policy mix. The answer was no, since a weaker exchange rate of the euro and a larger current account surplus of Euroland as a consequence of the proposed policy mix (tight fiscal in any case and relatively loose monetary policy in times of recession) would be less of a drawback than generally estimated. Section III.D argued that prices and hence temporary inflation differentials instead of fiscal policies constitute the appropriate adjustment mechanism for territorial differences within Euroland. Thus, the proposed policy 
mix which rests on tight fiscal policy is corroborated again.

In section IV.A, the main conclusions with respect to the policy mix were explained in terms of a model developed by Demertzis, Hughes Hallett, Viegi (1999) and justified in detail with polito-economic considerations. Special emphasis was given to the role of the Euro-11 in the proposal for the policy mix. In section IV.B the remaining and important uncertainties connected with the proposed policy mix were disclosed and discussed. It turned out that there is not a strong economic argument for fiscal policy co-ordination per se but at least for some explicit co-ordination between fiscal and monetary policy if national finance ministers have in turn to convey a strong message about the aggregate (ideally) restrictive fiscal policy stance in Euroland (via the ECOFIN). As the main reason it was identified that a quid pro quo for this message is a monetary policy which reacts to the business cycle stance within the bounds of price stability (rule with escape clause). However, the remaining necessity to ex ante solve some incentive problems for the fiscal and monetary policy players was identified as well. Finally, the interest rate increase by the ECB in November 1999 was judged to be a logical step per se and in line with the arguments brought forward and the policy mix developed in this paper (although an increasingly tight fiscal policy stance might have been preferred).

The covered period of the recommended policy-mix was rather short. The purpose of this paper was to examine the episode of the repo rate cut by the ECB in early 1999 as an illustrative example of a potential new policy-mix under EMU. Actually, after we have already passed two and a half years since the adoption of the euro, it should be the time to evaluate the actually implemented policy-mix with the benefit of the hindsight. Future work should perform a projection of the future stance of the euro-zone economies and provide a resultant appropriate policy-mix.

\section{Acknowledgement}

This contribution heavily relies on a paper prepared in close co-operation with Daniel Gros, CEPS, Brussels, for the Eurobriefing 'Do We Need an Economic Government for the EU? How to Organise the Co-ordination of Economic Policies? How to Organise an Appropriate and Balanced Policy Mix in the EU Which Contributes to Economic Growth and Employment', November 4, 1999, Committee on Economic and Monetary and Affairs of the European Parliament 
and Friedrich-Ebert-Foundation, Brussels. This paper has also been accepted for the Annual Meeting of the European Public Choice Society, Siena/Italy, 26-29 April 2000. I would like to thank Bernd Hayo, Georgetown University, and two anonymous referees for their valuable comments.

Date accepted: August 2001

\section{References}

Alesina, A. and Gatti, R. (1995), "Independent Central Banks: Low Inflation at No Cost?", American Economic Review, Vol. 85, pp. 196-200.

Alesina, A. and Perotti, R. (1995), "Fiscal Expansion and Adjustments in OECD Countries", in: Economic Policy, Vol. 10, pp. 205-248.

Belke, A. (1998), Expert-Statement in the Public Hearing on 'Asymmetric Shock or Shock Specific to One Country: On the Need of a Stability Fund Under EMU', European Parliament, Committee on Economic and Monetary Affairs and Industrial Policy, 2 September 1998, Brussels.

Belke, A. (1999), Towards an Appropriate and Balanced Policy Mix under EMU: Coordination of Macroeconomic Policies?, Paper prepared for the Eurobriefing 'Do We Need an Economic Government for the EU?', 4 November 1999, Brussels, Committee on Economic and Monetary and Affairs of the European Parliament and FriedrichEbert-Stiftung.

Belke, A. and Gros, D. (1998), "Asymmetric Shocks and EMU: Is a Stability Fund Needed?", in: Intereconomics - Review of International Trade and Development, Vol. 33, pp. 274-288.

Bogai, D. (1999), "Europäisierung der Beschäftigungspolitik?”, in: Wirtschaftsdienst, 1999/IX, pp. 555-561.

Brandner, P., Diabalek, L. and Schuberth, H. (1998), "Structural Budget Deficits and Sustainability of Fiscal Positions in die European Union", manuscript, Austrian National Bank, February.

Buiter, W. (1999), “Alice in Wonderland”, CEPR Policy Paper No. 1, London.

Buti, M., Sapir, A. (eds., 1998), Economic Policy in EMU, Oxford University Press.

Campillo, P. and Miron, J. (1997), "Why Does Inflation Differ across Countries?, in:

Reducing Inflation, Chicago, NBER Studies in Business Cycles, 30, pp. 335-357.

Centre for Economic Policy Research (1998), "The ECB: Safe at Any Speed?",

Monitoring the European Central Bank (MECB) 1, by Begg, David, Paul de Grauwe, Francesco Giavazzi, Harald Uhlig and Charles Wyplosz, Centre for EconomicPolicy Research, London.

Centre for Economic Policy Research (1999), Dominique Strauss-Kahn - Address on the

Occasion of CEPR's 15th Anniversary, London, 9 November 1998.

Centre for Economic Policy Research (1999a), “The Monitoring the European Central 
Bank (MECB) Update", September.

Clarida, R., Gali, J. and Gertler, M. (1998), "Monetary Policy Rules in Practice: Some Inter-national Evidence", European Economic Review, Vol. 42, pp. 1033-1067.

Commission of the European Communities (1997), "Economic Policy in EMU", Part B, Specific Topics, Economics Papers, DGII, No. 125, November.

Coppel, J., Durand, M. and Viscio, I. (2000), "EMU, the Euro and the European Policy Mix”, OECD Economics Department Working Papers No. 232, Paris.

Demertzis, M., Hughes Hallett, A. and Viegi, N. (1999), “An Independent Central Bank Faced with Elected Covernments”, CEPR Discussion Paper No. 2219, August, London.

Deutsche Bundesbank (1999), "Der Arbeitsmarkt in der Europäischen Währungsunion", in: Monatsberichte der Deutschen Bundesbank, Oktober, pp. 47-59.

Emerson, M. (1999), "Euro Strategies for Business - Going for AAA", Report of a CEPS

Working Party, Centre for European Policy Studies, Brussels.

European Central Bank (1999), "Monthly Report", June, Frankfurt.

Franckel, J.A. and Rockett, K.E. (1988), "International Policy Co-ordination When Policymakers Do Not Agree on the True Model”, in: American Economic Review, Papers and Proceedings, pp. 318-340.

Gretschmann, K. (1999), "Makropolitik im Euroraum: Das Zusammenspiel von Geldpolitik, Finanzpolitik und Tarifpolitik", Speech given at the "Arbeitskreis: Wirtschaftspolitik in der Europäischen Wirtschafts- und Währungsunion', List Gesellschaft, 27 October 1999, Frankfurt/Main.

Gros, D., Blanchard, O., Emerson, M., Mayer, Th., Saint-Paul, G., Sinn, H.-W. and Tabellini, G. (1999), "Macroeconomic Policy in the First Year of Euroland", 1st Annual Report of the CEPS Macroeconomic Policy Group, Centre for European Policy Studies, Brussels.

Gros, D. and Thygesen, N. (1998), "European Monetary Integration”, 2nd ed., Harlow.

Härtel, H.-H. (1999), "Makroökonomische Politik in der Europäischen Währungsunion”, in: Wirtschaftsdienst, 1999/II, pp. 116 - 121.

Hardes, H.-D. (1999), "Zur Frage der Notwendigkeit einer strategischen Koordinierung der Beschäftigungspolitik in Europa”, in: Mitteilungen aus der Arbeitsmarkt- und Berufsforschung, 2/1999, pp. 203-218.

Hatzius, J. and Mayer, Th. (1998), "Monetarism and the Taylor Rule", Goldman Sachs, The European Economic Analyst, Frankfurt, December.

Institut für Arbeitsmarkt- und Berufsforschung (1999), "Rolle der Europäischen Union in der Beschäftigungspolitik”, IAB-Kurzbericht Nr. 13 vom 23.09.1999.

Institute of World Economics (1999), "Euroland: Geldpolitik regt Konjunktur an nationale Inflationsraten divergieren", 27./28. Dezember, Kiel.

International Monetary Fund (1998), "World Economic Outlook", Washington/DC, May. Kösters, W. and Kotz, H.-H. (1999), "Perspectives on the Policy Mix in EMU”, Frankfurt, Bochum, mimeo.

Kollintzas, T., Philippopoulos, A. and Vassilatos, V. (1999), "Normative Aspects of Fiscal 
Policy in an Economic Union: A Review", CEPR Discussion Paper No. 2212, London.

Kotz, H.-H. (1998), "Binnenmarkt und Währungsunion: Verknüpfungslogik, Mikro- und

Makro-Folgen”, in: Welfens, P.J.J., Eichhorn, B., Palinkas, P. (eds.), Euro - Neues Geld für Europa, Campus-Verlag, Frankfurt/Main.

Lesch, H. (2000), "Brauchen wir eine europäische Beschäftigungspolitik?”, in: Politik und Zeitgeschichte, B14-15, Beilage zur Wochenzeitung Das Parlament, Bonn, pp. 14.

Levin, A.T., Rogers, J.H. and Tryon, R.W. (1997), "A Guide to FRB/GLOBAL", International Finance Discussion Paper No. 588, August.

Mayer, Th. (1999), "The ECBs Policy: The View from the Market, The European Economics Analyst, Goldman Sachs, Frankfurt.

McCallum, B.T. (1987), "The Case for Rules in the Conduct of Monetary Policy, in: Weltwirtschaftliches Archiv, Vol. 123, pp. 415-429.

Mélitz, J. (1997), "Some Cross-Country Evidence about Debt, Deficits and the Behaviour of Monetary and Fiscal Authorities, CEPR Discussion Paper No. 1653, London.

Padoa-Schioppa, T. (2000), "An Institutional Glossary of the Eurosystem", Paper prepared for the Conference on The Constitution of the Eurosystem: the Views of the EP and the ECB, 8 March, Frankfurt/Main.

Posen, A. (1997), "Lessons from the Bundesbank on the Occasion of its 40th (and second to last?) Birthday?", Discussion Paper 97-4, Institute for International Economics, Washington.

Randzio-Plath, C. (2000), "A New Political Culture in the EU Democratic Accountability of the ECB, Center for European Integration Studies Working Paper B4, Bonn.

Sachverständigenrat zur Begutachtung der gesamtwirtschaftlichen Entwicklung (1998), "Vor weitreichenden Entscheidungen", Jahresgutachten 1998/99, Stuttgart.

Soskice, D. and Iversen, T. (1998), "Multiple Wage-Bargaining Systems in the Single European Currency Area, in: Oxford Review of Economic Policy, Vol. 14, pp. 110123.

Taylor, J.B. (1993), "Discretion versus Policy Rules in Practice", Carnegie Rochester Conference on Public Policy, Vol. 39, pp. 195-214.

Taylor, J.B. (1998), “A Historical Analysis of Monetary Policy Rules, NBER Working Paper No. 6768, National Bureau of Economic Research, Cambridge/MA.

von Hagen, J. (1998), "Money Growth Targeting", Centre for European Integration Studies, University of Bonn, May 1998.

Welsch, H. (1998), "Domestic Fiscal Policy in a Monetary Union: What Are the Spillovers?", Volkswirtschaftliche Reihe Institut für Volkswirtschaftslehre I, V-19298, Universität Oldenburg. 